\title{
The Relationship between Sports Sponsorship and Brand Value: Case Study of Tahincioğlu Basketball Super League Name Sponsorship
}

\author{
Özlem IŞIK İNAN and Y. Aytül DAĞLI EKMEKÇİ
}

\begin{abstract}
It is seen that sport with many different sub-branches and categories has become an important branch of industry in terms of providing economic gain and creating employment. With the growth of the sports industry, the marketing of goods and services that are directly or indirectly related to sports has become remarkable. Not only the companies that produce sports goods and services, but also the companies that produce non-sports goods and services try to take part in the sports sector through sponsorship by recognizing the impact of sports on people. With the sponsorship of sports teams, leagues, federations or organizations, many brands, products and businesses become more recognized and increase brand value and indirect sales. The aim of this study is to reveal the relationship between sports sponsorship and brand value. The questionnaire method was used to learn the opinions of the fans and to measure the relationship between sports sponsorship and brand value. The scales were the Communication Companies Sport Sponsorship Scale (Ercan and Özbek, 2017), and the Brand Value Scale (Yoo and Donthu, 2001; Taşkın and Koşat2016). The 697 data sets obtained from the five competitions were subjected to correlation and regression analysis. As a result of the statistical analyzes, when the relationship between the perspective to the sponsor brand and the sub-dimensions of brand value was examined, a weak and positive relationship with perceived quality and brand loyalty, and a high and positive relationship with brand awareness was found. However, there was a very weak and positive relationship between the perspective to the sports sponsorship and the perceived quality and brand loyalty and a weak and positive relationship with the brand awareness. In general, when the whole effect of sport sponsorship to the brand value is analyzing, it is seen that it has a moderate and positive effect.
\end{abstract}

Keywords - Sport sponsorship, Brand value, Name sponsorship.

\section{INTRODUCTION}

Sports industry includes sports facilities, sports organizations and activities, sports tourism, sports equipment, sports technology, sports hardware, e-sports, athlete nutrition, athlete health and other relevant areas (Connor and Mazanov, 2010: 31; Ekmekçi and Dağlı Ekmekçi, 2010:24; Argan and Katırc1, 2012:6; Ünal and Ramazanoğlu, 2013: 37;Alkibay, 2015:196;Tekin and EroğluEskicioğlu, 2015:15).

As sports has become prevalent, the marketing of goods and

Y. Aytül DAĞLI EKMEKÇİ, Assistant Professor, Pamukkale University, Turkey.

Özlem IŞIK İNAN, Pamukkale University, Turkey. services that are directly or indirectly related to sports came into view. Not only the companies that produce sports goods and services, but also the companies that produce non-sports goods and services started to take part in sports marketing by recognizing the impact of sports on people (Argan and Katırc1, 2012:6).

Sponsorship means covering the necessary resources to be able to organize programs and activities through sponsor or sponsors. In comprehensive commercial sponsorships, intermediary institutions play a huge role in the organization of big activities or leagues by throwing together the sponsors (Madrill and O'Reilly, 2010: 134).

Sponsorship is a means of marketing communication which allows an enterprise to advertise correctly and effectively and create positive image on the target market devoted to the good or the brand via an activity or event (Bennet, 1999). Sponsorship is seen on the areas such as culture-art, adventuretravelling, social and sports sponsorships. Among the sponsorship areas, sports sponsorship takes the most common and popular place (Çoban, 2003:219; Tan andPyun, 2018: 1).

In real terms, sponsorship agreements have been practiced in the last 20 years in Turkey. However, in Europe and US. sponsorship has been used as the most effective marketing communication tool (Gümüş and Erdem, 2014: 2).Euroleague sponsorship of Turkish Airlines, official sponsorship agreements of Tadım, Nesine.com and SEK brands are examples of international sports sponsorship.

With sponsorship, while brands benefit from sports for effective branding and increasing market share, at the same time main source of income of sports teams, athletes, leagues and federations is formed (Tan and Pyun 2018: 1).

When in sports sponsorship practice, enterprises need to choose the most appropriate one according to their own purposes and goals (Çiftçibaşı, 2017: 41). Sports sponsorship is realized as individual athlete sponsorship, sports team sponsorship, sports organizations sponsorship, sports broadcasting sponsorship, sports facilities sponsorship, sports institutions sponsorship.

Marketing goals of sponsorship placing the good to the market, advertising a new good or service, promoting the use or sale of the good, encouraging the dealers, supporting international marketing and utilizing to new studies and making changes in marketing policies. 
Enterprises provides a competitive advantage by differentiating their products through the help of brand, moreover they have the chance of giving romanticism and personality to their products (Dicle, 2017: 46).

Brand value with the consumer-based perspective is defined as when both have the same marketing stimulus and product features, consumers react differently to a focus brand and a generic product (Yoo and Donthu, 2001: 1). Especially sports sponsorships provide advantage in creating brand value as a result of the effects of emotions and being exposed to intensive visual (Davies et al., 2006: 33).

Aaker (1992) explains brand value (brand equity concept) with five factors. However, those brand value factors are related highly and complete one another.

1- Brand Loyalty

2- Brand Name Awareness

3- Perceived brand quality

4- Brand associations

5- Other proprietary brand assets

Impacts of sport sponsorships are such impacts to develop positive attitude; brand placing and creating brand reputation in the mind of the target market, creating brand/good name awareness, creating or developing brand image, increasing sales and improving social relationships (Drennan and Cornwell, 2004: 1124; Masterman, 2007: 3; Başar, 2018: 171).

Thanks to sponsorships the attitude on the organizations symbolizing entertainment and positive effect will be conveyed to the brands. However, for the bond to be strong, sponsorships need to be for a long time. It is seen that consumers perceiving rapport between the sponsor and the organization think positively about sponsorship for the organization. Thus, brand image transfer and awareness of sponsor enterprise increases, and positive attitude is exhibited towards the sponsor brand. Brand name awareness and reputation of the sponsor brand that has high level of positive attitude should increase as its consumers have more information (Donald and Cornwell, 2003: 378-381).

\section{The Purpose, Importance, Method Of The Research AND CHOICE OF THE PARTICIPANTS}

This research aims to determine how strong sports sponsorship can influence brand value. As basketball catches many people's fancy in Turkey and it has a high rating, sponsorship of the name sponsor of Turkish basketball league is chosen as the field to study.

According to a research conducted for the 2017-2018 season, the number of spectator attendance was determined as 542.735 in Tahincioğlu Basketball Super League. In the second half of 2018-2019 season, we went to the determined Basketball Super League competitions and conducted questionnaire to volunteer fans. It is seen that the collected 895 data set is between $99 \%$ confidence interval and 5\% error margin and can represent the universe.

As the questionnaire form, two dimensions of "Communication Companies Sports Sponsorship Scale" of which validity and reliability tests were done by Ercan and Özbek in 2017 and "Brand Value Scale" developed by Yooand Donthu (2001), validity and reliability tested by Taşkın and Koşat (2016).

Research hypothesis is " $\mathrm{H} 1$ : There is a relationship between the viewpoint of the Basketball fans for sports sponsorship and the sub dimensions of brand value of the sponsor enterprise". With the 332 data collected from the first two competitions to test the functionality of the questions added to the scales, statistically analyzed as the pilot scheme (Teijlingen and Hunley,2001:1). The questionnaire was finalized by checking the functionality of the items on the scale in sub dimensions and item reliability. Main conduct was performed with the 42item questionnaire.

Bartlett test and Kaiser-Meyer-Olkin (KMO) are the tests that are mostly used to check if the data is appropriate for the factor analysis, before conducting it. (Bozkır, 2005: 18). While conducting explanatory factor analysis, KMO (Kaiser-MeyerOlkin).70 and more is okay, between .08- .09 is perfect for Sample Qualification Test and for the data to be appropriate for factor analysis Barlett Sphericity Test should be statistically significant (Field, 2009: 647; Yaşlıoğlu, 2017: 7576). KMO of Sport Sponsorship scale is .000, significance level .924 and KMO of brand value scale is.000 significance level. 932. With these figures, scales are evaluated as valid. Reliability of Sports sponsorship scale $\alpha=.923$, reliability of the subdimension viewpoint for sponsorship is $\alpha=.857$, reliability of the subdimension viewpoint for the sponsor brand is $\alpha=801$ 'dir. The reliability of the Brand value scale is $\alpha=.916$, brand name awareness subdimension is $\alpha=.765$, brand loyalty subdimension is $\alpha=.798$ and perceived quality subdimension is $\alpha=816$. In accordance with the results, the reliability of both questionnaires and subdimensions is high in reflecting the present state. 


\section{A. Demographic Findings of the Participants}

\begin{tabular}{|c|c|c|c|c|c|c|c|}
\hline & Qualities & $\mathbf{f}$ & $\%$ & & Qualities & f & $\%$ \\
\hline 苟 & $\begin{array}{l}\text { Female } \\
\text { Male } \\
\text { Total }\end{array}$ & 503 & $\begin{array}{l}43 . \\
8 \\
56 . \\
2 \\
100\end{array}$ & 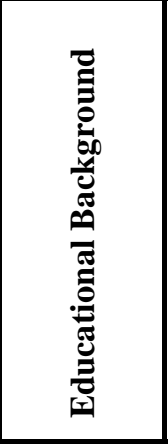 & $\begin{array}{l}\text { High School } \\
\text { Associate Degree } \\
\text { Bachelor's degree } \\
\text { Master } \\
\text { PhD } \\
\text { Total }\end{array}$ & $\begin{array}{l}21 \\
10 \\
9 \\
12 \\
9 \\
55 \\
9 \\
77 \\
\mathbf{8 9} \\
\mathbf{5} \\
\end{array}$ & $\begin{array}{l}2.3 \\
12 . \\
2 \\
14 . \\
4 \\
62 . \\
5 \\
8.6 \\
100\end{array}$ \\
\hline$\underset{0}{4}$ & $\begin{array}{l}18-20 \\
21-25 \\
26-30 \\
31-40 \\
41-50 \\
51 \text { and over } \\
\text { Total }\end{array}$ & $\begin{array}{l}118 \\
289 \\
125 \\
182 \\
123 \\
58\end{array}$ & $\begin{array}{l}13 . \\
2 \\
32 . \\
3 \\
14 . \\
0 \\
20 . \\
3 \\
13 . \\
7 \\
6.5 \\
100\end{array}$ & 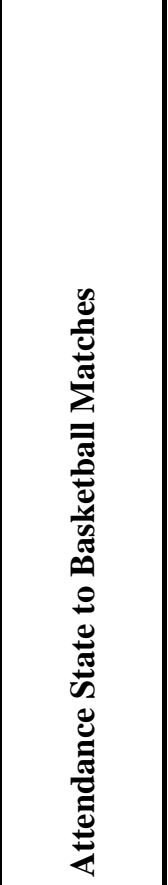 & $\begin{array}{l}\text { All Matches } \\
\text { All Matches of the } \\
\text { Favorite Team } \\
10 \text { match and more in a } \\
\text { season } \\
\text { 6-10 Match in a season } \\
\text { 3-5 Match in a season } \\
\text { 1-2 Match in a season } \\
\text { Total }\end{array}$ & $\begin{array}{l}39 \\
10 \\
5 \\
79 \\
\\
97 \\
\\
13 \\
8 \\
43 \\
8 \\
89 \\
\mathbf{5}\end{array}$ & $\begin{array}{l}4,2 \\
11 . \\
2 \\
\\
8.9 \\
\\
10 . \\
8 \\
\\
15 . \\
5 \\
48 . \\
9 \\
100\end{array}$ \\
\hline 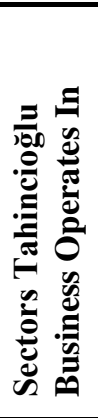 & $\begin{array}{l}\text { Textile } \\
\text { Construction } \\
\text { Food - Agriculture } \\
\text { Media - } \\
\text { Communication } \\
\text { Transportation } \\
\text { Education } \\
\text { Tourism } \\
\text { Total }\end{array}$ & $\begin{array}{l}8 \\
697 \\
171 \\
8 \\
5 \\
3 \\
3 \\
895\end{array}$ & $\begin{array}{l}0.9 \\
77 . \\
9 \\
19 . \\
1 \\
0.9 \\
0.6 \\
0.3 \\
0.3 \\
\mathbf{1 0 0}\end{array}$ & 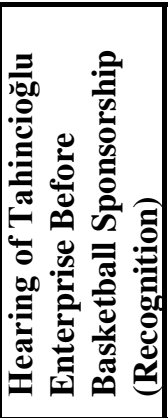 & $\begin{array}{l}\text { Yes } \\
\text { No } \\
\text { Total }\end{array}$ & $\begin{array}{l}32 \\
7 \\
56 \\
8 \\
\\
\mathbf{8 9} \\
\mathbf{5}\end{array}$ & $\begin{array}{l}36, \\
5 \\
63, \\
5 \\
\\
100\end{array}$ \\
\hline
\end{tabular}


TABLE II. KOLMOGOROV-SMIRNOV AND SHAPHIRO-WILK TEST RESUltS OF SUBDIMENSIONS

\begin{tabular}{|l|llll|lll|}
\hline & \multicolumn{4}{l|}{ Kolmogorov-Smirnov(a) } & \multicolumn{2}{l|}{ Shapiro-Wilk } \\
\hline \hline & Statistic & df & Sig. & Statistic & df & Sig. \\
\hline \hline $\begin{array}{l}\text { View Point for Sport } \\
\text { Sponsorship }\end{array}$ &, 114 & 697 &, 000 &, 923 & 697 &, 000 \\
\hline \hline $\begin{array}{l}\text { View Point for the Sponsor } \\
\text { Brand }\end{array}$ &, 077 & 697 &, 000 &, 958 & 697 &, 000 \\
\hline \hline Perceived Brand Quality &, 078 & 697 &, 000 &, 981 & 697 &, 000 \\
\hline \hline Brand Name Awareness &, 104 & 697 &, 000 &, 964 & 697 &, 000 \\
\hline \hline Brand Loyalty &, 075 & 697 &, 000 &, 981 & 697 &, 000 \\
\hline
\end{tabular}

a Lilliefors Significance Correction

For nonparametric data which are not distributed normally, Spearman Correlation is used (Eymen, 2017: 87). In addition, Regression analysis is also conducted.

\section{B. Correlation Analysis Related with Research Variables}

In correlation analysis the direction and severity of the relationship between two variables is calculated. Correlation coefficient is between -1 and +1 . The symbol indicates the

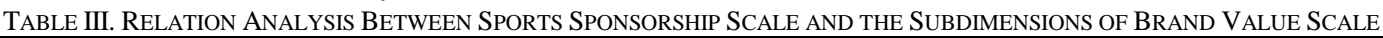

\begin{tabular}{|c|c|c|c|c|c|c|}
\hline \multicolumn{2}{|l|}{ Variables } & \multirow{2}{*}{ 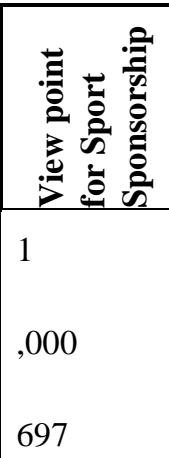 } & \multirow{2}{*}{ 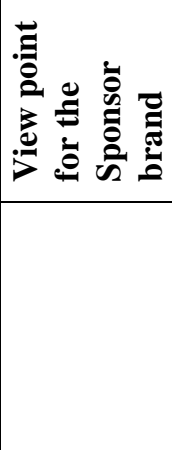 } & \multirow{2}{*}{ 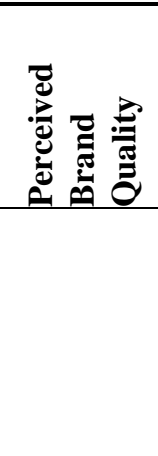 } & \multirow{2}{*}{ 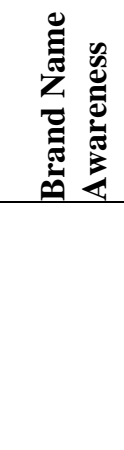 } & \multirow{2}{*}{ 흘 } \\
\hline $\begin{array}{l}\text { Viewpoint for } \\
\text { Sport } \\
\text { Sponsorship }\end{array}$ & $\begin{array}{l}\text { Spearman's rho Correlation } \\
\text { Sig. (2-tailed) } \\
\text { N }\end{array}$ & & & & & \\
\hline $\begin{array}{l}\text { View point for } \\
\text { the Sponsor } \\
\text { brand }\end{array}$ & $\begin{array}{l}\text { Spearman's rho Correlation } \\
\text { Sig. (2-tailed) } \\
\text { N }\end{array}$ & $\begin{array}{l}, 661(* *) \\
, 000 \\
697\end{array}$ & $\begin{array}{l}1 \\
, 000 \\
697\end{array}$ & & & \\
\hline $\begin{array}{l}\text { Perceived } \\
\text { Brand Quality }\end{array}$ & $\begin{array}{l}\text { Spearman's rho Correlation } \\
\text { Sig. (2-tailed) } \\
\text { N }\end{array}$ & $\begin{array}{l}\mathbf{1 6 5}(* *) \\
, 000 \\
912\end{array}$ & $\begin{array}{l}\mathbf{4 5 1}(* *) \\
, 000 \\
912\end{array}$ & $\begin{array}{l}1 \\
, 000 \\
912\end{array}$ & & \\
\hline $\begin{array}{l}\text { Brand Name } \\
\text { Awareness }\end{array}$ & $\begin{array}{l}\text { Spearman's rho Correlation } \\
\text { Sig. (2-tailed) } \\
\text { N }\end{array}$ & $\begin{array}{l}, \mathbf{4 9 2}(* *) \\
, 000 \\
912\end{array}$ & $\begin{array}{l}\mathbf{7 8 3}(* *) \\
, 000 \\
912\end{array}$ & $\begin{array}{l}, \mathbf{5 7 2}(* *) \\
, 000 \\
697\end{array}$ & $\begin{array}{l}1 \\
, 000 \\
912\end{array}$ & \\
\hline
\end{tabular}

direction of the relationship. (Eymen, 2007: 99-100; Field, 2009: 167-179). Correlation analysis is conducted to find if there is a relationship between the factors that belongs to two scales used in the research and if there is a relation; to find the direction and severity of this relation. Spearman Correlation coefficient was not made use of because the data did not scatter normally (Kalayc1, 2017:117). 


\begin{tabular}{|c|c|c|c|c|c|c|}
\hline \multirow{3}{*}{ Brand Loyalty } & Spearman's rho Correlation & ,244(**) & ,484(**) &, $716(* *)$ & ,730(** & 1 \\
\hline & Sig. (2-tailed) & ,000 &, 000 & ,000 & ,000 & ,000 \\
\hline & $\mathrm{N}$ & 912 & 912 & 912 & 912 & 912 \\
\hline
\end{tabular}

** CORRELATION IS SIGNIFICANT AT THE 0.01 LEVEL (2-TAILED).

Between the viewpoint for the sponsor brand subdimension and the perceived quality and brand loyalty subdimensions $(\mathrm{p}<0,01)$ of brand value sale there is a low and positive relationship (,451 and ,484) in terms of significancy, with brand name awareness subdimension $(\mathrm{p}<0,01)$ there is a high and positive relationship (,783) in terms of significany. Besides there is a very low relationship (,165 and ,244) in terms of significancy, between viewpoint for the sponsorship subdimension and the subdimensions perceived quality and brand loyalty $(\mathrm{p}<0,01)$, and with brand name awareness subdimension there is low level (,492) and positive relationship. In accordance with the results, H1 hypothesis is accepted. According to the results, the positive increase in viewpoint for the sports sponsor brand causes a significant positive increase in the subdimensions of brand value. Especially the positive change in the viewpoint for the sports sponsorship brand causes a high and positive increase in the

TABLE IV DESCRIPTIVENESS COEFFICIENT FOR 1. REGRESSION MODEL

\begin{tabular}{|c|c|c|c|c|c|c|c|}
\hline Model & $\mathbf{R}$ & $\mathbf{R}^{2}$ & \multicolumn{2}{|c|}{ Adjusted R Square } & \multicolumn{3}{|c|}{$\begin{array}{l}\text { Standard Error of the } \\
\text { Estimate }\end{array}$} \\
\hline 1 & ,792(a) & ,627 & \multicolumn{2}{|l|}{,626 } & \multicolumn{3}{|l|}{,48821 } \\
\hline \multicolumn{2}{|l|}{ Model } & $\begin{array}{l}\text { Sum of } \\
\text { Squares }\end{array}$ & Df. & \multicolumn{2}{|l|}{ Mean Square } & $\mathbf{F}$ & Sig \\
\hline 1 & Regression & 278,337 & 1 & & 278,337 & $\begin{array}{r}1167,77 \\
1\end{array}$ &, $000(a)$ \\
\hline \multicolumn{2}{|c|}{ Residual } & 165,653 & 695 & & & ,238 & \\
\hline \multicolumn{2}{|c|}{ Total } & 443,990 & 696 & & & & \\
\hline
\end{tabular}

a: Independent Variable: Viewpoint for Sport Sponsor b: Dependent Variable: Brand Name Awareness

It is seen that $62,7 \%$ of the change in brand name awareness the model is set as 1167,77 and $\mathrm{p}$ value as, $000 . \mathrm{P}<\alpha$ is explained by view point for sport sponsor brand. $\mathrm{F}$ value of $\quad(, 000<0,05)$ thus, model is statistically significant.

TABLE V. REGRESSION ANALYSIS RESULTS FOR THE 1. MODEL

\begin{tabular}{|c|c|c|c|c|c|c|}
\hline \multirow{2}{*}{\multicolumn{2}{|c|}{ Model }} & \multicolumn{2}{|c|}{$\begin{array}{l}\text { Unstandardized } \\
\text { Coefficients }\end{array}$} & \multirow{2}{*}{\begin{tabular}{|l|}
$\begin{array}{l}\text { Standardized } \\
\text { Coefficients }\end{array}$ \\
Beta \\
\end{tabular}} & \multirow[t]{2}{*}{$\mathbf{t}$} & \multirow[t]{2}{*}{ Sig. } \\
\hline & & $\beta$ & St. Error & & & \\
\hline \multirow[t]{2}{*}{1} & (Constant) & ,387 & ,099 & & 3,912 &, 000 \\
\hline & $\begin{array}{l}\text { Viewpoint for } \\
\text { Sponsor Brand }\end{array}$ & ,844 & ,025 & ,792 & 34,173 &, 000 \\
\hline
\end{tabular}

Beta $(\beta)$ coefficient expresses Regression coefficient used for regressione quation and significancy level of these (Eymen, 2007: 95). Thus, it can be said that while other variables are fixed (sig. ,000 level of significance), a unit of change in the subdimension of viewpoint for sport sponsor brand makes a positive impact of 0,84 on brand name awareness.

Regression analysis results related with the Viewpoint for Sport sponsor brand (Tahincioğlu Realty enterprise) subdimension on brand loyalty are displayed below on the (2. Regression model)Table 6. And Table 7. 
TABLE VI. DesCRIPTIVENESS COEFFICIENT MODEL FOR 2. REgReSSION MODEL

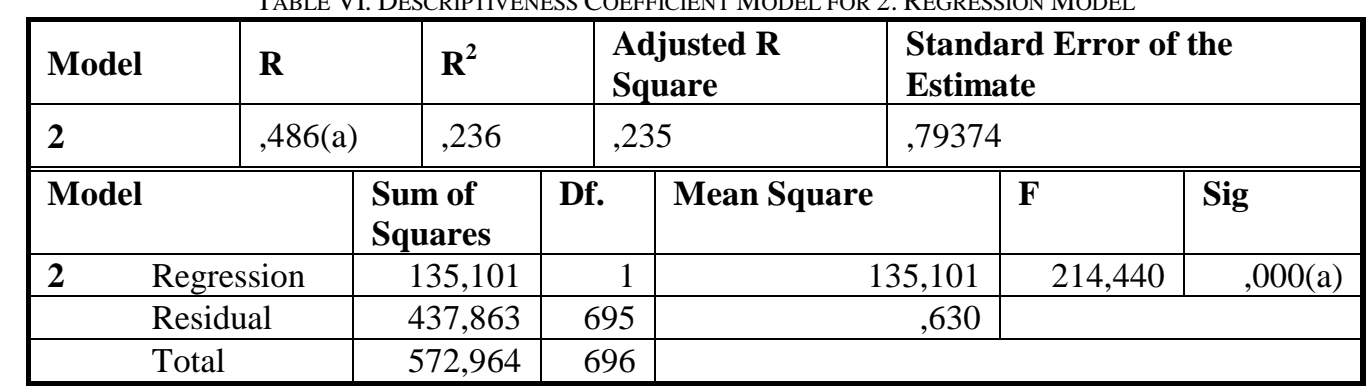

a: Independent Variable: Viewpoint for Sport Sponsorship b: Dependent Variable: BrandLoyalty

It is seen that $23,6 \%$ of the total change of brand loyalty is the mode is set as 214,44 and $p, 000 . P<\alpha(0,000<0,05)$ thus, explained by viewpoint for sports sponsor brand. F value of model is statistically significant.

TABLE VII. REGRESSION ANALYSIS RESULTS FOR 2. MODEL

\begin{tabular}{|c|c|c|c|c|c|c|}
\hline \multirow{2}{*}{\multicolumn{2}{|c|}{ Model }} & \multicolumn{2}{|c|}{$\begin{array}{l}\text { Unstandardized } \\
\text { Coefficients }\end{array}$} & \multirow{2}{*}{ 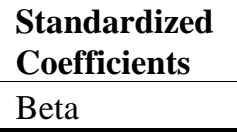 } & \multirow[t]{2}{*}{$\mathbf{T}$} & \multirow[t]{2}{*}{ Sig. } \\
\hline & & $\beta$ & St. Error & & & \\
\hline \multirow[t]{2}{*}{2} & (Constant) & 994 & 161 & & 6,182 & $\overline{000}$ \\
\hline & $\begin{array}{l}\text { Viewpoint for } \\
\text { Sponsor Brand }\end{array}$ &, 588 &, 040 & ,486 & 14,644 &, 000 \\
\hline
\end{tabular}

Interpreting the Beta $(\beta)$ coefficient, it can be said that a unit of increase in viewpoint for sports sponsorship brand will make a 0,58 positive impact on brand loyalty while other variables ae fixed (sig. ,000 level of significance).
Regression Analysis results related with the impact of the subdimension of viewpoint for sports sponsor brand (Tahincioğlu Realty enterprise) on perceived quality are (3. Regression model) displayed onTable8. andTable9.

TABLE VIII. DESCRIPTIVENESS COEFFICIENT FOR 3. REGRESSION MODEL

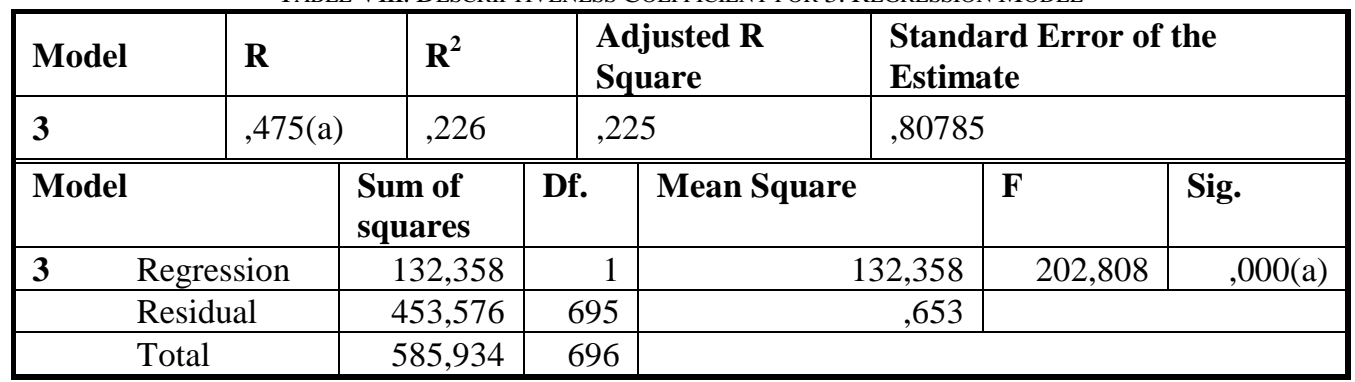

a: Independent Variable: Viewpoint for Sports Sponsorship b: Dependent Variable: Perceived quality

It displays that $22,6 \%$ of total change of perceived quality is the model is set as 202,80 and $\mathrm{p}, 000 . \mathrm{P}<\alpha(0,000<0,05)$ thus, model is statistically significant. explained by viewpoint for sports sponsor brand. F value of

TABLE IX. REGRESSION ANALYSIS RESULTS FOR 3. MODEL

\begin{tabular}{|c|c|c|c|c|c|c|}
\hline \multirow{2}{*}{\multicolumn{2}{|c|}{ Model }} & \multicolumn{2}{|c|}{$\begin{array}{l}\text { Unstandardized } \\
\text { Coefficients }\end{array}$} & \multirow{2}{*}{\begin{tabular}{|l|}
$\begin{array}{l}\text { Standardized } \\
\text { Coefficients }\end{array}$ \\
Beta \\
\end{tabular}} & \multirow[t]{2}{*}{$\mathbf{t}$} & \multirow[t]{2}{*}{ Sig. } \\
\hline & & $\beta$ & St. Error & & & \\
\hline \multirow[t]{2}{*}{3} & (Constant) & ,895 &, 164 & & 5,473 &, 000 \\
\hline & $\begin{array}{l}\text { View point for } \\
\text { Sponsor Brand }\end{array}$ &, 582 &, 041 & ,475 & 14,241 &, 000 \\
\hline
\end{tabular}

Interpreting the Beta $(\beta)$ coefficient, it can be said that a unit of change in viewpoint for sports sponsor brand will have a
0,58 positive impact on perceived quality (sig. ,000 level of significance). 


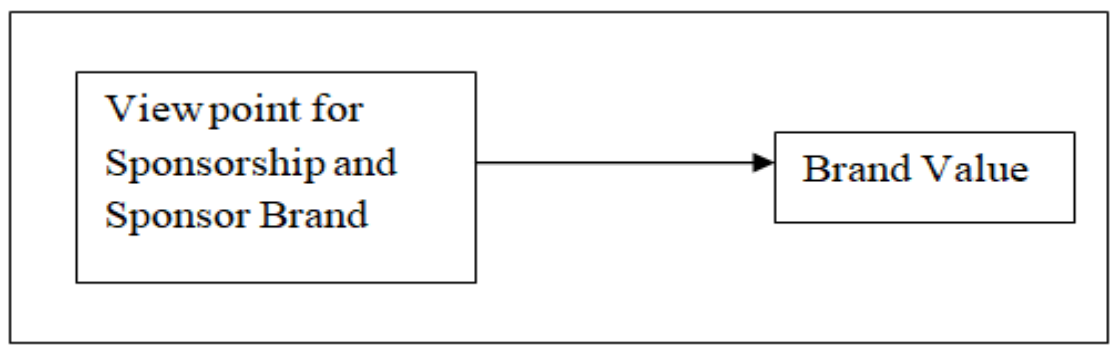

Fig. 1. Relationship Diagram between General Viewpoint for Sports Sponsorship and Brand Value

Regression analysis results related with general sports sponsorship and its impact on brand value are displayed on (4.

Regression model) Table10. and Table11.

TABLE X. DESCRIPTIVENESS COEFFICIENT FOR 4. REGRESSION MODEL

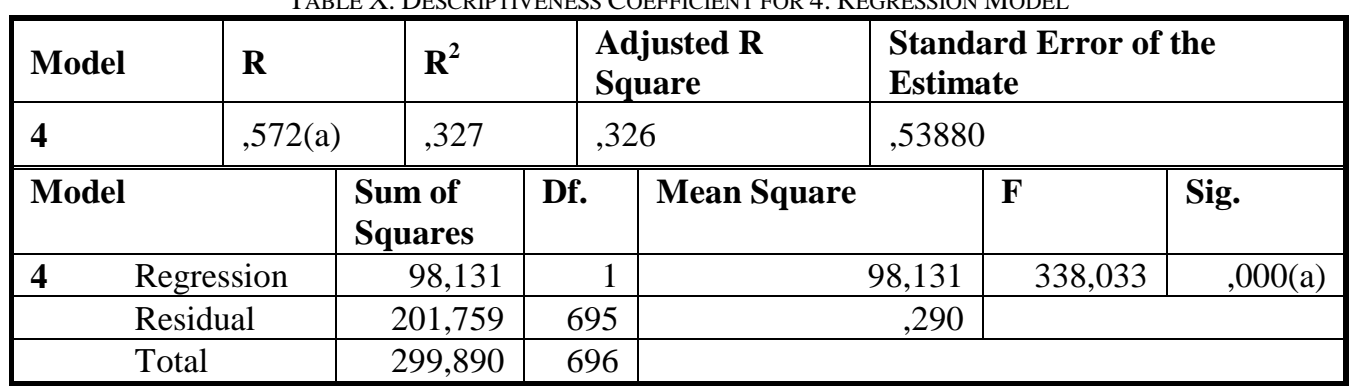

a: Independent Variable: Sports Sponsorship b: Dependent Variable: Brand Value

model is set as 338,03 and $\mathrm{p}, 000 . \mathrm{P}<\alpha(0,000<0,05)$ thus,

It is seen that $32,7 \%$ of the total change in brand value is

model is statistically significant. explained by viewpoint for sports sponsorship. $\mathrm{F}$ value of the

TABLE XI. REGRESSION ANALYSIS RESULTS FOR 4. MODEL

\begin{tabular}{|c|c|c|c|c|c|c|}
\hline \multirow{2}{*}{\multicolumn{2}{|c|}{ Model }} & \multicolumn{2}{|c|}{$\begin{array}{l}\text { Unstandardized } \\
\text { Coefficients }\end{array}$} & \multirow{2}{*}{$\begin{array}{l}\text { Standardized } \\
\text { Coefficients } \\
\text { Beta }\end{array}$} & \multirow[t]{2}{*}{$\mathbf{t}$} & \multirow[t]{2}{*}{ Sig. } \\
\hline & & B & St. Error & & & \\
\hline 4 & (Constant) & 2,409 & ,091 & & 26,492 &, 000 \\
\hline & $\begin{array}{l}\text { View point for } \\
\text { Sponsorship and } \\
\text { Sponsor Brand }\end{array}$ & ,480 & ,026 & ,572 & 18,386 &, 000 \\
\hline
\end{tabular}

a: Independent Variable: Sports Sponsorship

It can be said that a unit change in viewpoint for sports sponsorship can make a 0,48 positive impact on brand value.

\section{DISCUSSION AND RESULT}

Analyzing the relationship between viewpoint for the sponsor brand and dimensions of brand value, there is a medium and positive relationship. According to this result, as viewpoint of the fans for sports sponsorship increases positively, brand name awareness increases at high level and medium increase is observed in the brand perceived quality.

Regression model analysis results show that viewpoint for the sponsor brand explains $62,7 \%$ of total change of the sponsor brand name awareness, $23,6 \%$ of total change of brand loyalty and $22,6 \%$ of perceived quality. Besides analyzing the significance level of Regression coefficient used for $\beta$ coefficient Regressione quation, it is confirmed that a unit of change in viewpoint for the sponsor brand subdimension has a 0.84 unit of positive influence on brand b: Dependent Variable: Brand Value name awareness, 0.58 unit on brand loyalty and 0.58 on perceived quality.

In the Regression model results where the relationship between overview for sports sponsorship and brand value is shown, it is seen that $32,7 \%$ of the total change in brand value is explained by the general viewpoint for the sport sponsorship. Besides analyzing the significance level of Regression coefficient used in $\beta$ coefficient Regressione quation, it is seen that a unit of change in general viewpoint for the sport sponsorship has 0.48 unit of effect on brand value.

Considering the results of the study, it is seen that sport sponsorship is highly related with brand name awareness, brand loyalty and especially perceived quality. Thus, that choosing the appropriate sport sponsorship in accordance with the goals and the target market will increase the expected impact should be considered and choices should be made more carefully with detailed actions.

\section{REFERENCES}

[1] Aaker, D. A. (1992). "The Value of Brand Equity". Journal of Business Strategy, 13 (4), 27-32. 
https://doi.org/10.1108/eb039503

[2] Alkibay, S. (2015). Sporda Markalam ve Marka Değeri Yaratma. M. Arslan içinde, Masamızda Marka Sohbetleri (s. 195-220). İstanbul: Beta Yayıncilik.

[3] Argan, M. ve Katırc1, H. (2002). Spor Pazarlaması. Ankara: Nobel Yayın Dağıtım.

[4] Bozkır, Ö. (2015). Faktör Analizi ile Üniversiteye Giriş Sınavlarındaki Başarı Durumlarına Göre İllerin Siralanması. İstanbul Ticaret Üniversitesi İstatistik Anabilim Dalı (Basılmamış Yüksek Lisans Tezi) . İstanbul.

[5] Connor, J. M. and Mazanov, J. (2010). "The inevitability of scandal: the lessons for sponsors and administrators". International Journal of Sports Marketing and Sponsorship, 11(3), 29-37. https://doi.org/10.1108/IJSMS-11-03-2010-B004

[6] Çiftçibaşı, G. C. (2017). Spor Pazarlaması ve Sponsorluk: Beşiktaş Jimnastik Kulübü ve Vodafone Arasındaki Sponsorluk İlișkisinde Taraftarların Tutumlarının İncelenmesi. Mehmet Akif Ersoy Üniversitesi, Sosyal Bilimler Enstitüsü, İșletme Ana Bilim Dalı Yüksek lisans Tezi. Burdur.

[7] Çoban, S. (2003). "Kurumsal İmaj Oluşturma Aacı Olarak Sponsorluk ve İnternet Uygulamaları". Süleyman Demirel Üniversitesi İktisadi ve İdari Bilimler Dergisi, 8 (2), 213-229.

[8] Davies, F., Veloutsou, C. and Costa, A. (2006). "Investigating the Influence of a Joint Sponsorship of Rival Teams on Supporter Attitudes and Brand Preferences". Journal of Marketing Communications, 12 (1), $31-48$. https://doi.org/10.1080/13527260500264574

[9] Dicle, A.B. (2018).Marka Değeri Algısı: Özel Hastanelere Yönelik Bir Uygulama. Acıbaden Mehmet Aydınlar Üniversitesi, Sağlık Bilimleri Enstitüsü, (Basılmamış Yüksek Lisans Tezi), İstanbul

[10] Donald, R. P. and Cornwell, B. T. (2003). "Brand Equity's Influence On Responses to Event Sponsorship". Journak of Product and Brand Management, 12 (6), 377-393. https://doi.org/10.1108/10610420310498803

[11] Drennan, J. C. and Cornwell, T. B. (2004). "Emerging Strategies for Sponsorship on the Internet". Journal of Marketing Management, 20:9 (10), 1123-1146. https://doi.org/10.1362/0267257042405231

[12] Ekmekçi, R. ve Dağlı Ekmekçi, A. Y. (2010). "Spor Pazarlaması". Pamukkale Journal of Sport Sciences, 1(1), 23-29.

[13] Ercan, Ö. ve Özbek, O. (2017). "İletișim Sirketlerinin Spor Sponsorluğu Ölçeğinin Güvenirlik ve Geçerlik Çalışması". International Journal of Human Sciences, 14(4), 3615-3625. https://doi.org/10.14687/jhs.v14i4.4622

[14] Eymen, E. (2007). SPSS 15.0 Veri Analiz Yöntemleri. İstatistik Merkezi Yayın No: 1.

[15] Field, A. (2009). Discovery Statistic Using SPSS (Third Editiona). London: SAGE Publications Ltd.

[16] Gümüş, S. ve Erdem, B. (2014). "Spor Sponsorluklarının Tüketici Tutumuna Etkisi, Hava Yolu Müșterileri Üzerine Bir İnceleme."International Anatolia Academic Online Journal, 2 (1), 1-25.

[17] Küçüksille, E. (2017). Basit Doğrusal Regresyon. Ş. Kalaycı içinde, SPSS Uygulamalı Çok Değiş̧kenli İstatistik Teknikleri (s. 199-201). Ankara: Dinamik Yayıncılık.

[18] Masterman, G. (2007). Sponsorship: For a Return on İnvestment. Londra: Routledge. https://doi.org/10.1016/B978-0-7506-8640-2.50010-2

[19] MEB. (2011). Sponsorluk. Ankara: T.C Milli Eğitim Bakanlığı, Halkla İlişkiler ve Organizasyon Hizmetleri.

[20] Tan, S. Y. and Pyun, D. Y. (2018). "The Effectiveness of Sponsorship of the F1 Singapore Grand Prix: Recall and Recognition". International Journal of Asian Business and Information Management, 9 (1), 1-12. https://doi.org/10.4018/IJABIM.2018010101

[21] Taşkın, E. ve Koşat, A. (2016). "Tüketicilerdeki Spor Sponsorluğu Algısın Marka Değeri Üzerine Etkisi". Dumlupınar Üniversitesi Sosyal Bilimler Dergisi, Özel Sayısı (Aralık), 1-17.

[22] Tekin, N. ve Eroğlu Eskicioğlu, Y. (2015). "Spor Sponsorluğu: Türk Hava Yolları - Türkiye Basketbol Federasyonu Örneği". SPpor Yönetimi ve Bilgi Teknolojileri Dergisi, 10 (1), 14-36.

[23] Teijlingen, E. R. and Hundley, V. (2001). "The importance of pilot studies". Social Research UPDATE University of Surrey, 35, 1-4
[24] Ünal, B. ve Ramazanoğlu, F. (2013). "Spor Medyasının Toplum Üzerindeki Sosyolojik Etkisi". Journal of Research in Education and Teaching, 2 (1), 36-46.

[25] Yaşlıoğlu, M. M. (2017). "Sosyal Bilimlerde Faktör Analizi ve Geçerlilik: Keşfedici ve Doğrulayıcı Faktör Analizlerinin Kullanılması". İstanbul Üniversitesi İșletme Fakültesi Dergisi, 46 (Özel Sayı), 74-85.

[26] Yoo, B. and Donthu, N. (2001). "Developing and validating a multidimensional consumer-based brand equity scale". Journal of Business Research, 52, 1-14. https://doi.org/10.1016/S0148-2963(99)00098-3

[27] Zdravkovic, S. and Till, B. D. (2012). "Enhancing Brand Image via Sponsorship". International Journal of Advertising, 31 (1), 113-132. https://doi.org/10.2501/JJA-31-1-113-132 